\title{
Hyalinization and Molecular Pathways Involved in Orthodontic Tooth Movement: A Systematic Review and Meta-Analysis
}

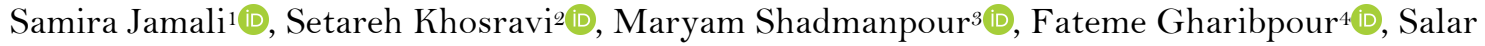 \\ Payahoo ${ }^{5}$ (D), Maryam Darvish ${ }^{(10}$
}

\footnotetext{
${ }^{1}$ Department of Endodontics, Stomatological Hospital, College of Stomatology, Xi'an Jiaotong University, Shaanxi, PR China. ${ }^{2}$ Department of Orthodontics, Shahed University of Medical Sciences, Tehran, Iran.

${ }^{3}$ Department of Orthodontics, School of Dentistry, Shiraz University of Medical Sciences, Shiraz, Iran.

${ }^{4}$ Dental Students' Research Committee, Department of Orthodontics, School of Dentistry, Isfahan University of Medical Sciences, Isfahan, Iran.

${ }^{5}$ Department of Oral and Maxillofacial Radiology, Dental School, Urmia University of Medical Sciences, Urmia, Iran.

${ }^{6}$ Department of Endodontics, School of Dentistry, Kerman University of Medical Sciences, Kerman, Iran.
}

Author to whom correspondence should be addressed: Samira Jamali, Department of Endodontics, Stomatological Hospital, College of Stomatology, Xi'an Jiaotong University, Shaanxi 710004, PR China. E-mail: samira.jamali90@yahoo.com.

Academic Editor: Alessandro Leite Cavalcanti

Received: 28 November 2019 / Accepted: 25 June 2020 / Published: 29 July 2020

How to cite this article: Jamali S, Khosravi S, Shadmanpour M, Gharibpour F, Payahoo S, Darvish M. Hyalinization and molecular pathways involved in orthodontic tooth movement: a systematic review and meta-analysis. Pesqui Bras Odontopediatria Clín Integr. 2020; 20:e5408. https://doi.org/10.1590/pboci.2020.148

\begin{abstract}
Objective: To systematically review the hyalinization of experimental tooth movement in humans and animals. Material and Methods: The electronic databases of MEDLINE, PubMed, Cochrane Library, Embase, Institute for Scientific Information, and Google Scholar were searched for performing a systematic review of the related literature published until 2019. Moreover, Endnote X9 software was utilized to manage electronic titles. The searches were fulfilled using keywords of "hyalinization," "orthodontic tooth movement" OR “OTM" AND "periodontal ligament" OR "PDL," "molecular pathways," AND "mechanical cell." Therefore, this systematic review was conducted based on the key consideration of the Preferred Reporting Items for Systematic Reviews and Meta-Analyses (PRISMA) statement. Results: Forces ranged between 2.3 and $50 \mathrm{CN}$ had been applied. According to the research design, incisors had been included in two experiments, whereas maxillary molars had been displaced by tipping forces in another rat examination. However, a majority of investigations had stated that hyalinization had firstly appeared within the first 24 hours. Moreover, the amount of prostaglandin-end peroxide synthase 2 (PTGS2) had been positively related to force term and size utilizing Western blotching. As PTGS2 had been included in the prostaglandin E2 (PGE2) metabolism, the up-regulation of PTGS2 gene expression could be connected with that of PGE2 emission. Conclusion: Gene expression in connection with force term and size and also the first signalling pathways were recognized utilizing protein-protein interactions (PPIs).
\end{abstract}

Keywords: Orthodontics; Tooth Movement Techniques; Study Characteristics. 


\section{Introduction}

Orthodontics has been introduced as a specific discipline devoted to examinations and practices of the tooth movement across the bone [1]. The reason for orthodontic therapy is thus moving the teeth as effectively as possible with negligible unfavorable impacts on the teeth and the supporting tissues [2]. In this line, numerous studies have reported molecular, cellular, and tissue-level reactions associated with orthodontic tooth movement (OTM) [3-5]. One study in this respect had also indicated that an ideal force system could be critical for a sufficiently biological reaction within the periodontal ligament (PDL) [6]. It had been correspondingly demonstrated that variables including force type and amount or treatment duration (i.e., term) could be coherent with unfavorable tissue responses like sterile necrosis or root resorption.

The emergence of the necrotic tissue, known as hyalinization, has been taken into account as a vital element within the tooth movement procedure [7-9]. Primarily established on histological investigations, pressure, and a tension side have also been recognized during the OTM procedure $[7,8,10]$. Hyalinization can be accordingly sterile necrosis at the pressure region of PDL observed amid the early phases of the OTM, and broad hyaline zones can thus result in imperative delay within the tooth movement procedure $[7,11,12]$. In related studies, hyalinization has been seemingly found within the initial phase of OTM, and small hyalinized patches have been additionally observed within the afterward phases [13,14]. Hyalinization amid the later stages of OTM has incompletely justified clinical contrasts within the tooth movement rate between different patients [15]. Some studies have also demonstrated the impacts of orthodontic forces on the teeth and their encompassing tissues and recognized the basic phases in the OTM procedure [16,17]. Human osteoblasts (hOBs) and human periodontal ligament cells (hPDLCs) have been identified as kinds of cells beginning from the mesenchymal ancestry contributing significantly to OTM.

In contrast to hOBs as a characterized cell type, hPDLCs exhibit a blended populace of generally fibroblast-like cells $[17,18]$. From amongst them, mesenchymal stem cells (MSCs) would be of extraordinary significance as the source of forebears mindful for recovering and re-modulating not as that for PDL itself but the alveolar bone [19]. To better understand the morphological changes during the OTM procedure, it would be vital to explain cellular and molecular signalling pathways between and inside such cell types [17].

Therefore, this study's primary objective was to conduct a systematic review of hyalinization associated with the experimental tooth movement in humans and animals. The secondary purpose was to understand mechano-dependent molecular pathways involved in the OTM procedure.

\section{Material and Methods}

\section{Search Strategy}

The electronic databases of MEDLINE, PubMed, Cochrane Library, Embase, Institute for Scientific Information (ISI) were searched to provide a systematic review of the related literature published until 2019. Moreover, Endnote X9 software was utilized to manage electronic titles. Searches were performed with mesh terms: $\quad(((($ "Tooth Movement Techniques/adverse effects"[Mesh] OR "Tooth Movement Techniques/methods"[Mesh] )) OR "Tooth Movement Techniques"[Mesh]) AND "Periodontal Ligament"[Mesh]) AND "Adverse Outcome Pathways"[Mesh]) AND "Index of Orthodontic Treatment Need" $[$ Mesh $]$. Therefore, this systematic review was conducted based on the key consideration of the Preferred Reporting Items for Systematic Reviews and Meta-Analyses (PRISMA) statement.

The inclusion criteria applied in this study were as follows: 1) Primary data sources; 2) Humans and animals used as species; 3) Data concerning hyalinization; 4) Mechanical push on the tooth and its 
encompassing tissues; 5) Utilization of two-dimensional (2D) or three-dimensional (3D) weight approach based on an in-vitro loading model; and 6) Key considerations, i.e., articles in English.

\section{Data Extraction and Method of Analysis}

The data have been extracted from the research included about the study, year, study design, force, sample size, time of sacrifice, cutting plane, first hyalinization, last hyalinization, gene symbol or metabolite, examined force applied, increase/decrease/ no change, change in relation to force magnitude, increase/decrease/ no change, substance secretion change to force duration, change about force magnitude. The quality of the studies included was assessed using the Meta-Analysis and Review of Animal Data [20]. For Data extraction, two reviewers blind and independently extracted data from the abstract and full text of studies included. Moreover, ES, with a 95\% confidence interval (CI), were calculated. Random effects were used to deal with potential heterogeneity, and $\mathrm{I}^{2}$ showed heterogeneity. The Meta-analysis and forest plots have been evaluated using a software program (i.e., Comprehensive Meta-Analysis Stata V14).

\section{Results}

\section{Study Selection Process}

As the primary set-up data, 231 potentially important topics and abstracts were discovered through manual and electronic searches on the given databases. During the primary phase of the research selection, a total of 184 articles were also neglected with regard to their titles and abstracts. Also, a total number of 47 full-text studies were completely assessed for the moment phase. Then, 42 articles were excluded since they were not in agreement with the inclusion criteria. Ultimately, five studies meeting the inclusion criteria were reviewed systematically. In the secondary set-up, a total number of 314 potentially relevant topics and abstracts were observed during manual and electronic searches. Then, within the first phase of the selection, 246 articles were removed about their titles and abstracts. In the second phase, 68 full-text studies were comprehensively assessed. Afterwards, 61 articles were excluded at this phase, as they had no compliance with the inclusion criteria of this study. Ultimately, 11 articles met the inclusion criteria in the present study (Figure 1).

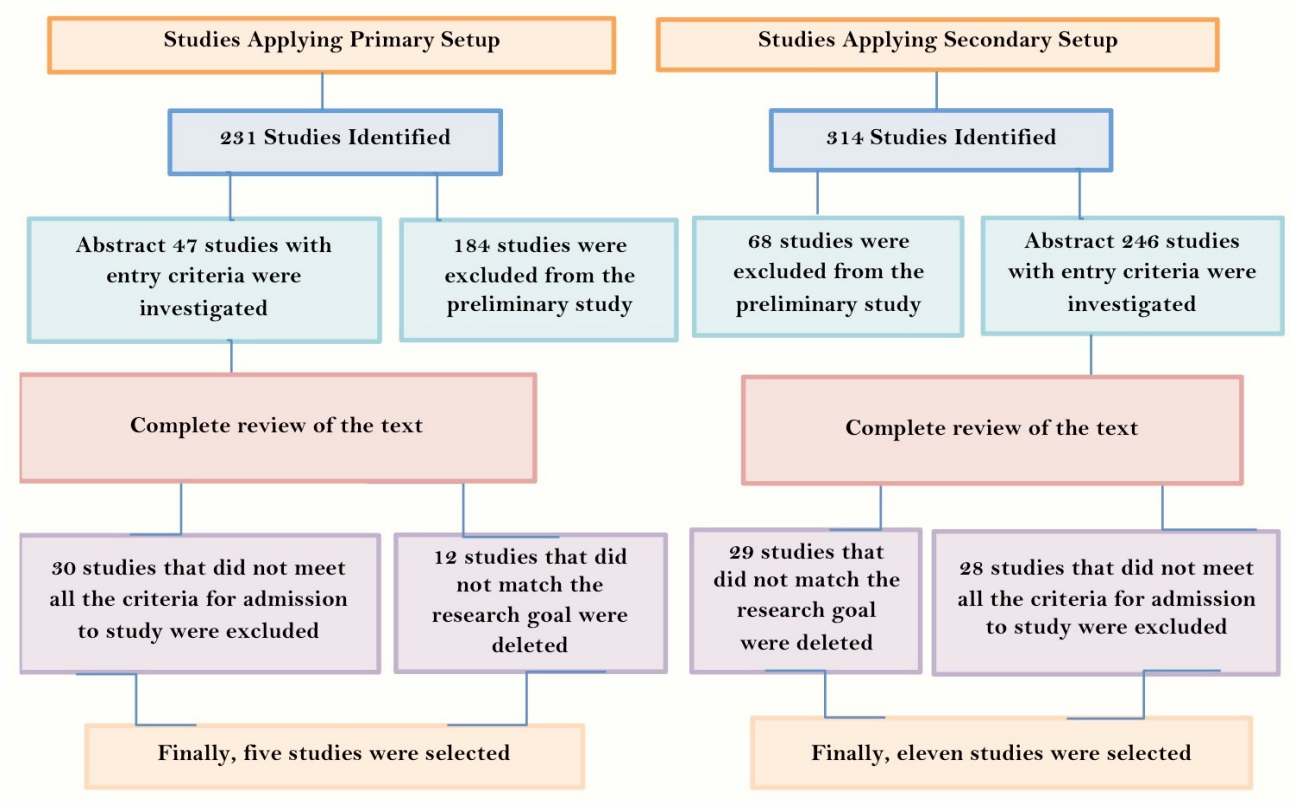

Figure 1. Study attrition diagram. 
Hyalinization during OTM Procedure

The overall results presented in Table 1 are summarized as follows [7,21-24]: In 4 out of the five selected articles, the experiments had been carried out in rats $[7,21,22,24]$. As well, the animals included in the experiments were a total number of 177 , and the experimental interval had been between 1 and 56 days. Moreover, the applied forces had been ranged between 2.3 and $50 \mathrm{cN}$. In terms of research design, incisors had been included in two experiments, whereas maxillary molars had been displaced by tipping forces in another rat examination. However, most investigations had stated that hyalinization had first appeared within the first 24 hours. Additionally, an investigation dealing with $\operatorname{dogs}(n=1)$ had revealed that diverse force levels had been applied at a range of $50 \mathrm{CN}$ and the teeth had been fundamentally displaced. One study had further observed the necrotic tissue in the rest phase and after the acceleration one after 28 days [23].

Table1. Selected studies to enter a systematic review.

\begin{tabular}{|c|c|c|c|c|c|c|c|c|}
\hline \multirow[t]{2}{*}{ Authors } & \multirow[t]{2}{*}{ Year } & \multirow[t]{2}{*}{ Species } & \multirow[t]{2}{*}{$\mathbf{N}$} & \multirow[t]{2}{*}{ Force } & \multirow{2}{*}{$\begin{array}{r}\text { Time of } \\
\text { Sacrifice }\end{array}$} & \multirow{2}{*}{$\begin{array}{l}\text { Cutting } \\
\text { Plane }\end{array}$} & \multicolumn{2}{|c|}{ Hyalinization } \\
\hline & & & & & & & First & Last \\
\hline Cuoghi et al. [7] & 2019 & Rat & 42 & 50 & $1,3,5$ & Horizontal & 1 day & 12 days \\
\hline $\begin{array}{l}\text { Kraiwattanapong } \\
\left.\text { et al. [ } \begin{array}{ll}2 & 1\end{array}\right]\end{array}$ & 2018 & Rat & 40 & 40,50 & $7,14,21,28$ & Horizontal & $\begin{array}{c}7 \text { and } \\
14 \text { days }\end{array}$ & 28 days \\
\hline $\begin{array}{l}\text { Tomizuka et al. } \\
{[22]}\end{array}$ & 2007 & Rat & 43 & $\begin{array}{c}2.3 \rightarrow 13.5 \\
5 \rightarrow 13.5\end{array}$ & $1,3,7,10,14$ & Horizontal & 1 day & 10 days \\
\hline Iino et al. [23] & 2007 & Dog & 12 & 50 & $7,14,28,56$ & $\begin{array}{c}\text { Saggital } \\
\text { (Mesial-Distal) }\end{array}$ & 7 days & 28 days \\
\hline Kohno et al. [24] & 2002 & Rat & 40 & $\begin{array}{l}1.2,3.6 \\
6.5,10\end{array}$ & 7,14 & Horizontal & 7 days & 14 days \\
\hline
\end{tabular}

Molecular Pathways in OTM Procedure

It should be noted that compression forces extending from 0.25 and $5 \mathrm{~g} / \mathrm{cm}^{2}$ have been connected with cells in two-dimensional culture. Unquestionably, the foremost widely utilized compressive force has been $2 \mathrm{~g} / \mathrm{cm}^{2}$. Force length and size have also been dependent on the scaffold employed. In most cases, platforms fabricated from the collagen gel and poly-lactic-co-glycolic acid (PLGA) have also been connected. In one study [25], a hydrophilically-altered poly (L-lactide) (PLLA) matrix had been correspondingly utilized. Then, the collagen gel scaffolds had been used with force magnitudes changing from $0.5 \mathrm{~g} / \mathrm{cm}^{2}$ to $9.5 \mathrm{~g} / \mathrm{cm}^{2}$ and the foremost widely applied force had been $6 \mathrm{~g} / \mathrm{cm}^{2}$. The force had also been connected for 0.5 to 72 hours. The force levels between 5 and $35 \mathrm{~g} / \mathrm{cm}^{2}$ were utilized to the cells placed in the PLGA scaffolds. Thus, the foremost widely connected force had been $25 \mathrm{~g} / \mathrm{cm}^{2}$. Notably, the force application term had been reported between 3 and 72 h. Therefore, the study utilizing a hydrophilically-balanced PLLA matrix [25] had used force sizes between 5 and $35 \mathrm{~g} / \mathrm{cm}^{2}$. Afterwards, the force application term had switched between 1 and 14 days. A total overview of the genes and metabolites inspected in $2 \mathrm{D}$ and $3 \mathrm{D}$ WAB examinations and specifications of their expression are provided in supplements 2 and $3(2 \mathrm{D})$ and supplement $4(3 \mathrm{D})$.

Extraordinary consideration has been also paid to the hPDLCs as the foremost studied cell type among the examinations as well as their significant contribution to OTM procedures. However, the first inspected qualities and metabolites in connection with hPDLCs have been TNF super-family portion 11 (TNFSF 11), prostaglandin-end peroxide synthase 2 (PTGS2), TNF receptor super-family portion 11B (TNFRSF11B), and prostaglandin E2 (PGE2). It should be noted that points of interest regarding their expression or secretion counted the information at which the time centers or force sizes had raised slightly were summarized. Most inspected genes had also utilized hPDLCs. Thus, this study summarized the obtained 
information to the foremost commonly genes inspected and materials in this kind of cell to clarify the commitment of the hPDLCs in OTM procedure on molecular levels (Table 2, Figures 2, 3, 4, and 5). The genes, including PTGS2, TNFSF11, and PGE2, have also been called osteoclast genesis inducers, and TNFRSF 1 1 B has been referred to as the osteoclast genesis suppressor. As the PTGS2 had been included in the prostaglandin E2 system, the up-regulation of PTGS2 gene expression was connected with that of PGE2 discharge in all studies. TNFRSF 11B, also alluded to the osteoprotegerin (OPG), was TNFSF 11's antagonist, which could hinder osteoclast genesis.

Many studies using 2D WAB in-vitro loading had further shown no alteration in the quality expression with a special case of 2 ponders with detailed or transitory down-regulation. Considering protein discharge, results had been conflicting. In any case, most studies had detailed a reduction in protein emission or had reported no change. Moreover, outputs obtained by examinations in studies utilizing 3D WAB in-vitro stacking had been opposite about the scaffold employed. Another study using the collagen gel scaffolds had further demonstrated an increment in TNFRSF11B quality expression. However, in each study using the PLGA scaffolds, the TNFRSF11B discharge's decline had been emphatically related to constraining the size and adversely associated with constraining length. As an exception, comparing the TNFSF 11 and TNFRSF 11B quality expressions within the previously mentioned studies, it had been reported that regulating TNFRSF 11B had been parallel with a quick up-regulation of TNFSF 11 in 3D WAB in-vitro stacking. These two genes had also exhibited opponents in the bone turnover control, which had been clarified as a great exhibition of the cyclic alterations within the bone metabolism on the compression side amid the OTM procedure.

Moreover, researchers had proposed that down-regulating TNFSF 11 in afterward phases could be related to other inducers for delayed osteoclast genesis advancement. TNFSF 11 can also play a pivotal part in bone resorption on the compression side during the OTM procedure, actuating the osteoclast arrangement. TNFSF 11 has also been introduced as expanded gene expression in each study, utilizing $2 \mathrm{D}$ WAB in-vitro loading. Many research studies using TNFSF 11 quality expression and protein secretion have been further emphatically related to duration and greatness, coming to the most extreme expression levels after 12-24 hours of applying the force. In this respect, a study utilizing the $3 \mathrm{D}$ WAB in-vitro stacking had shown a detailed increment within the TNFSF 11 emission, a majority of them after 6 hours of applying the force. However, in the cells developed in PLGA scaffolds, there was a positive relationship between constraint size and gene. The PTGS2 gene expression level had been expanded by constraining applications in both $2 \mathrm{D}$ and 3D ponders. Many 2D WAB examinations had thus reported that PTGS2 was positively correlated with the length of the examination and gene expression.

Nevertheless, studies using the 3D WAB in-vitro loading had demonstrated that PTGS 2 could be adversely associated with force term and emphatically connected with force size. Put it differently; PTGS2 amount had appeared to have a positive relationship with force term and size according to Western blotching. As PTGS2 had been included in the PGE2, the up-regulation of PTGS2 gene expression had been also connected to that of PGE2 emission (Table 2 and Figures 2, 3, 4, and 5). 
Table 2. Selected studies to enter systematic review and meta-analysis.

\begin{tabular}{|c|c|c|c|c|c|c|c|c|c|}
\hline \multirow[t]{2}{*}{ Study } & \multirow{2}{*}{$\begin{array}{c}\text { Gene Symbol or } \\
\text { Metabolite }\end{array}$} & \multicolumn{2}{|c|}{ Examined Force Applied } & \multirow{2}{*}{$\begin{array}{c}\text { Increase / } \\
\text { Decrease / No } \\
\text { Change }\end{array}$} & \multirow{2}{*}{$\begin{array}{c}\text { Gene Expression } \\
\text { Change About } \\
\text { Force Duration (h) }\end{array}$} & \multirow{2}{*}{$\begin{array}{c}\text { Change About } \\
\text { Force } \\
\text { Magnitude } \\
\left(\mathrm{g} / \mathrm{cm}^{2}\right)\end{array}$} & \multirow{2}{*}{$\begin{array}{l}\text { Increase / } \\
\text { Decrease / } \\
\text { No Change }\end{array}$} & \multirow{2}{*}{$\begin{array}{c}\text { Substance } \\
\text { Secretion Change } \\
\text { About Force } \\
\text { Duration (h) }\end{array}$} & \multirow{2}{*}{$\begin{array}{c}\text { Change } \\
\text { About Force } \\
\text { Magnitude } \\
\left(\mathrm{g} / \mathrm{cm}^{2}\right)\end{array}$} \\
\hline & & $\begin{array}{l}\text { Duration } \\
\text { (h) }\end{array}$ & $\begin{array}{l}\text { Magnitude } \\
\left(\mathrm{g} / \mathrm{cm}^{2}\right)\end{array}$ & & & & & & \\
\hline \multirow[t]{3}{*}{ Benjakul et al. [26] } & PGE2 & 48 & 1.5 & NR & NR & NR & $\begin{array}{c}\text { Increase } \\
\text { (qPCR: GAPDH) }\end{array}$ & 48 & 1.5 \\
\hline & TNFRSF $11 \mathrm{~B}$ & & & $\begin{array}{c}\text { No Change } \\
\text { (qPCR: GAPDH) }\end{array}$ & NR & NR & No change & & \\
\hline & TNFSF 11 & & & $\begin{array}{c}\text { Increase } \\
\text { (qPCR: GAPDH) }\end{array}$ & 48 & 1.5 & $\begin{array}{c}\text { Increase } \\
\text { (qPCR: GAPDH) }\end{array}$ & 48 & 1.5 \\
\hline \multirow[t]{2}{*}{ Liao et al. [25] } & TNFRSF $11 \mathrm{~B}$ & $\begin{array}{l}1 \mathrm{~d} ; 3 \mathrm{~d} ; 7 \\
\mathrm{~d} ; 14 \mathrm{~d}\end{array}$ & $\begin{array}{l}5.0 ; 15.0 \\
25.0 ; 35.0\end{array}$ & $\begin{array}{c}\text { No Change } \\
\text { (qPCR: GAPDH) }\end{array}$ & 12 & 1.0 & NR & NR & NR \\
\hline & TNFSF 11 & & & $\begin{array}{c}\text { Increase } \\
\text { (qPCR: GAPDH) }\end{array}$ & 14 & 35.0 & NR & NR & NR \\
\hline \multirow[t]{4}{*}{ Yi et al. [27] } & PGE2 & 24 & 25.0 & NR & NR & NR & $\begin{array}{l}\text { Increase } \\
\text { (ELISA) }\end{array}$ & & \\
\hline & TNFSF 11 & & & $\begin{array}{l}\text { Increase } \\
\text { qPCR }\end{array}$ & 24 & 25.0 & Increase (WB) & 24 & 25.0 \\
\hline & PTGS2 & & & $\begin{array}{c}\text { Increase } \\
\text { (qPCR: GAPDH) }\end{array}$ & & & Increase (WB) & & \\
\hline & TNFRSF $11 \mathrm{~B}$ & & & $\begin{array}{c}\text { Decrease } \\
(\mathrm{qPCR}: \text { GAPDH })\end{array}$ & & & $\begin{array}{l}\text { No Change } \\
\text { (WB) }\end{array}$ & NR & NR \\
\hline \multirow[t]{3}{*}{ Li et al. [28] } & TNFRSF $11 \mathrm{~B}$ & $6 ; 24 ; 72$ & 25.0 & $\begin{array}{c}\text { Increase } \\
\text { (qPCR: GAPDH) }\end{array}$ & 6,72 & 25.0 & & NR & NR \\
\hline & PGE2 & & & NR & & & $\begin{array}{l}\text { Increase } \\
\text { (ELISA) }\end{array}$ & 24 & 25.0 \\
\hline & PTGS2 & & & $\begin{array}{c}\text { Increase } \\
\text { (qPCR: GAPDH) }\end{array}$ & 6 & 25 & NR & NR & NR \\
\hline \multirow[t]{4}{*}{ Jin et al. [29] } & PGE2 & $\begin{array}{c}0 ; 0.5 ; 3 \\
6 ; 12\end{array}$ & 2.0 & NR & & & $\begin{array}{l}\text { Increase } \\
\text { (ELISA) }\end{array}$ & 12 & 2.0 \\
\hline & PTGS2 & & & $\begin{array}{c}\text { Increase } \\
\text { (qPCR: GAPDH) }\end{array}$ & 12 & 2 & NR & NR & NR \\
\hline & TNFRSF $11 \mathrm{~B}$ & & & $\begin{array}{c}\text { No Change } \\
\text { (qPCR: GAPDH) }\end{array}$ & & & NR & NR & NR \\
\hline & $\begin{array}{c}\text { Nochange } \\
\text { (qPCR: GAPDH) }\end{array}$ & & & $\begin{array}{c}\text { Increase } \\
\text { (qPCR: GAPDH) }\end{array}$ & NR & NR & NR & NR & NR \\
\hline
\end{tabular}




\begin{tabular}{|c|c|c|c|c|c|c|c|c|c|}
\hline \multirow[t]{4}{*}{ Kirschneck et al. [30] } & PTGS2 & 24 & 2.0 & Increase & 24 & 2.0 & & & \\
\hline & PGE2 & & & $\begin{array}{c}\text { (qPCR: POL2RA) } \\
\text { NR }\end{array}$ & NR & NR & $\begin{array}{l}\text { Not Explicit } \\
\text { Lystated } \\
\text { (ELISA) }\end{array}$ & NR & NR \\
\hline & TNFRSF 11B & & & $\begin{array}{c}\text { No Change } \\
\text { (qPCR: POL2RA) }\end{array}$ & $\mathrm{NR}$ & $\mathrm{NR}$ & NR & NR & NR \\
\hline & TNFSF 11 & & & $\begin{array}{c}\text { Increase } \\
\text { (qPCR: POL2RA) }\end{array}$ & 24 & 2.0 & NR & NR & NR \\
\hline \multirow[t]{2}{*}{ Jianru et al. [31] } & TNFRSF 11B & $\begin{array}{c}3 ; 6 ; 12 \\
\text { (WB: } 12)\end{array}$ & 25.0 & $\begin{array}{l}\text { Decrease followed } \\
\text { by Increase } \\
\text { (qPCR: GAPDH) }\end{array}$ & 3,12 & 25.0 & Increase (WB) & 12 & 25.0 \\
\hline & TNFSF 11 & & & $\begin{array}{c}\text { Increase } \\
\text { (qPCR: GAPDH) }\end{array}$ & 6 & 25.0 & Increase (WB) & 12 & 25.0 \\
\hline \multirow[t]{2}{*}{ Proff et al. [32] } & PTGS2 & 24 & 2 & $\begin{array}{c}\text { Increase } \\
\text { (qPCR: POL2RA) }\end{array}$ & 24 & 2 & Increase (WB) & 24 & 2 \\
\hline & PGE2 & & & Increase (ELISA) & 24 & 2 & & & \\
\hline \multirow[t]{2}{*}{ Kim et al. [33] } & TNFRSF 11B & $\begin{array}{l}0.5 ; 2 ; 6 \\
24 ; 48\end{array}$ & 2.0 & $\begin{array}{l}\text { Down Regulated } \\
\text { (qPCR: GAPDH) }\end{array}$ & 6 & 2.0 & $\begin{array}{c}\text { Transitory Down } \\
\text { Regulation } \\
\text { (ELISA) }\end{array}$ & 6 & 2.0 \\
\hline & TNFSF 11 & & & $\begin{array}{c}\text { Increase } \\
\text { (qPCR: GAPDH) }\end{array}$ & 24 & 2.0 & $\begin{array}{l}\text { Increase } \\
\text { (ELISA }\end{array}$ & 48 & 2.0 \\
\hline \multirow[t]{2}{*}{ Mitsuhashi et al. [34] } & TNFSF 11 & $\begin{array}{c}1 ; 3 ; 6 ; 9 ; \\
12 ; 24\end{array}$ & 4.0 & $\begin{array}{l}\text { Temporary Increase } \\
\text { (qPCR: ACTNB) }\end{array}$ & 6,9 & 40 & NR & NR & $\mathrm{NR}$ \\
\hline & TNFRSF 11B & & & $\begin{array}{c}\text { No Change } \\
\text { (qPCR: ACTNB) }\end{array}$ & $\mathrm{NR}$ & NR & NR & NR & NR \\
\hline \multirow[t]{3}{*}{ Römer et al. [35] } & TNFSF 11 & 24 & 2 & $\begin{array}{l}\text { Increase (qPCR: } \\
\text { RNA-polymerase-2- } \\
\text { polypeptide A) }\end{array}$ & 24 & 2 & NR & NR & NR \\
\hline & PGE2 & & & NR & NR & NR & $\begin{array}{l}\text { Increase } \\
\text { (ELISA }\end{array}$ & 24 & 2 \\
\hline & TNFRSF 11B & & & $\begin{array}{l}\text { RNA-polymerase- } \\
\text { 2polypeptideA) }\end{array}$ & $\mathrm{NR}$ & NR & NR & NR & NR \\
\hline
\end{tabular}

NR: Not Reported; qPCR: Polymerase Chain Reaction. 


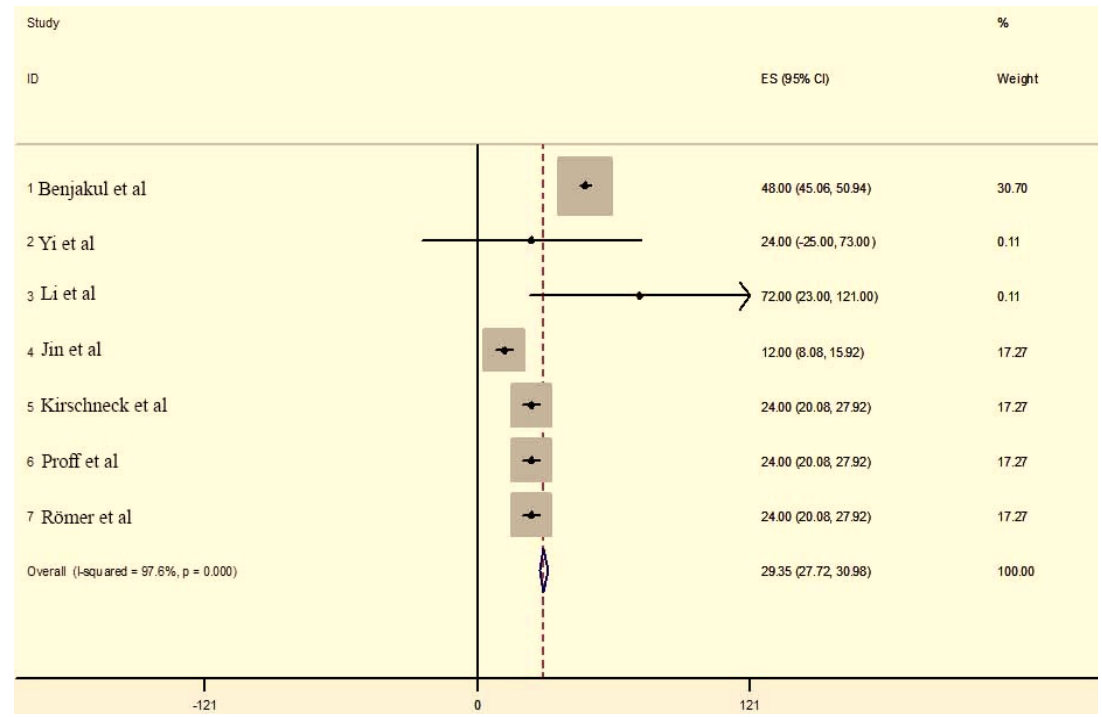

Figure 2. Forest plots of PGE2.

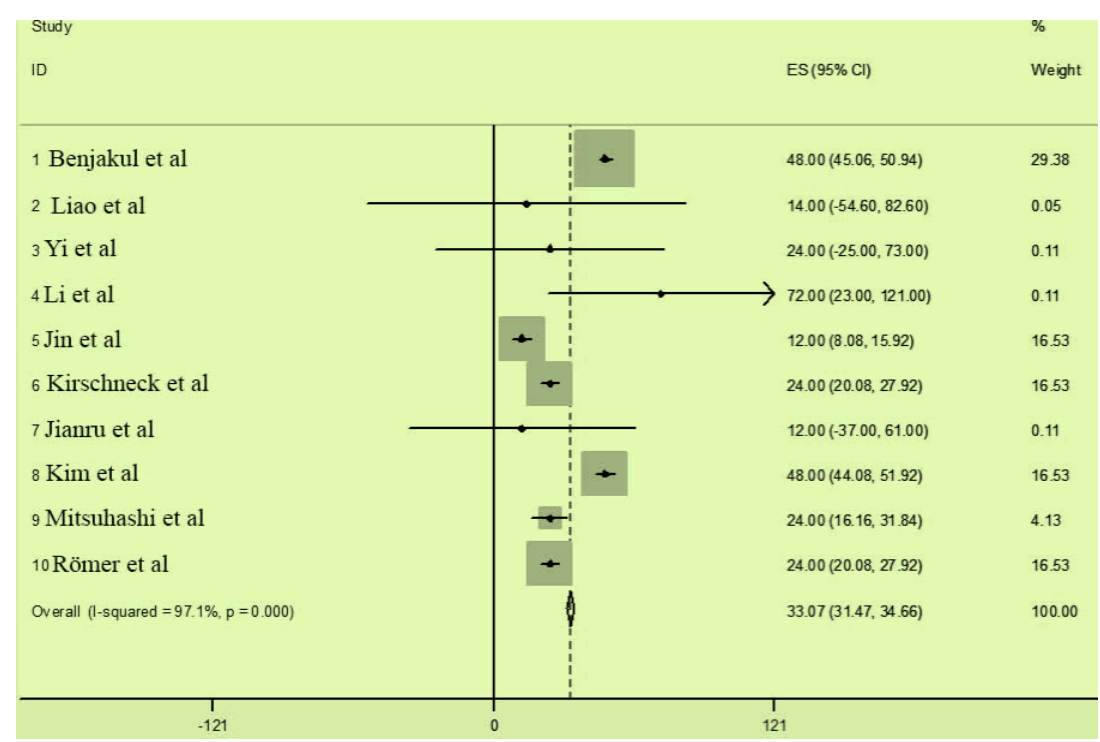

Figure 3. Forest plots of TNFRSF $11 \mathrm{~B}$.

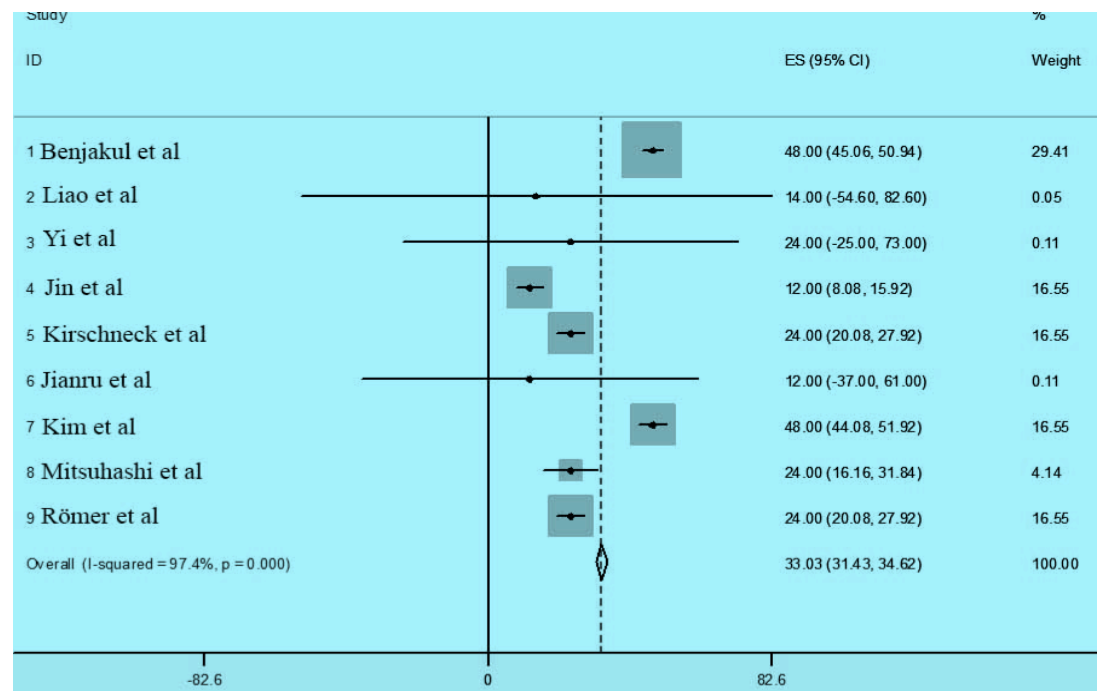

Figure 4. Forest plots of TNFSF 11. 


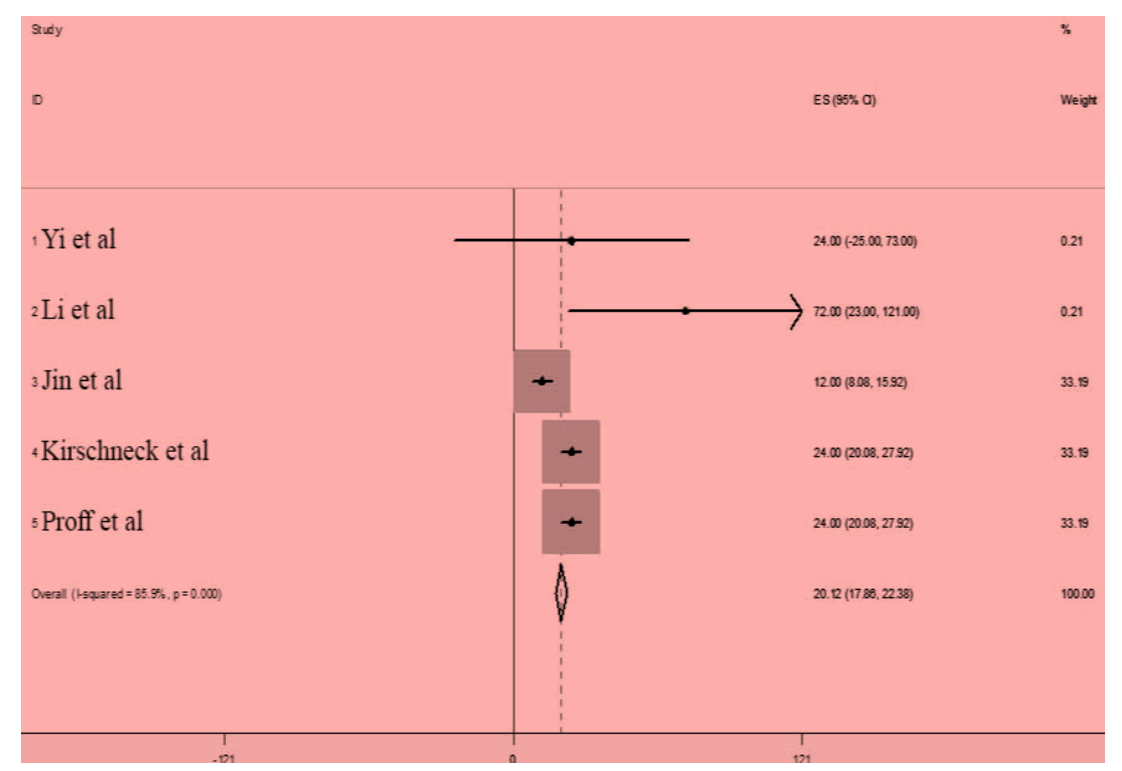

Figure 5. Forest plots of PTGS2.

\section{Discussion}

To meet the primary objective of this study, it was not conceivable to do a consequent meta-analysis because the information may not be fused for measurable investigations. So, a systematic review of existing information concerning hyalinization and tooth movement was conducted. In this respect, some studies had carried out tipping tooth movements that had led to uneven stretch and strain distributions within PDL. Such a test set-up had also provided the ground to initiate hyalinization with a generalizable manner. In addition, many investigations had adopted short experimentation intervals, raising the question if the linear stage of tooth movement had been ever come to a particular point or not. Normally, auxiliary modifications within the hard and the PDL during the tooth movement's distinctive phases can modify the local biomechanical context that results in modulating biological reactions [7,8]. Finally, the information revealed significant interindividual changes in biological reactions to a force that led to a challenging comparison between diverse studies. However, according to the previous systematic review on force magnitude connected with the OTM procedure [36-38], similar problems had been experienced [38].

In this review, it appeared that hyalinization in rats had occurred before the test phase compared with other species. In one other study, details showed that the alveolar bone in rats had a better thickness than that of humans [36]. It seemed that the osteoid layer alongside the bone surface was less inexhaustible in rats compared with humans, justifying quicker hyalinization. Moreover, smaller width of rats' PDL had induced higher power and generally higher neighborhood strain on the alveolar bone, resulting in decreased blood flow and creation of a necrotic region. The other clarification might be the greater rate of bone turnover amid the remodelling process occurrence in OTM procedure in rats compared with that in humans $[8,39,40]$.

To meet the secondary objective of this study, it was observed that the force application term within the examinations had seldom surpassed 72 hours. However, in many conditions, the force had been connected up to 24 and 48 hours. Although the first ten days had been crucially significant for the OTM procedure, the force application term in many studies had been inadequate to completely reach the atomic foundation of OTM procedure [17,40]. Furthermore, it should be noted cell practicality was also explored. Accordingly, most studies affirmed a reduction of the cell practicality caused by the force level and time [41,42]. It is accepted that a limitation, particularly within the $2 \mathrm{D}$ WAB in-vitro models, has threatened supplements and oxygen 
supplies within the weight zone. To particularly overcome the time impediment of the past models, the hydrophilically adjusted PLLA network as an unused platform for 3D groups had been presented [17,25]. So, the high scaffold might be utilized for up to 14 days with no influence on cells. KEGG paths recognized for all sets of qualities could also be significant for OTM procedure, and they could also be valuable sources for finding unused qualities that might influence OTM.

\section{Conclusion}

The in-vitro weight-loaded approach represents a basic and an exceptionally effective way to examine molecular events amid OTM procedure. Accordingly, 3D in-vitro weight approaches based on stacking models can be promising for further studies since they can provide more genuine in-vitro set-ups. Moreover, hyalinization can be taken into account as an unfavorable side effect of the OTM procedure. Furthermore, hyalinization and its conceivable relationships with strain levels in PDL and alveolar bone or the tooth movement rate after the introductory phase have been delineated in a small number of key considerations.

\section{Authors' Contributions}

\begin{tabular}{|c|c|c|}
\hline SJ & (D) 0000-0003-3803-1235 & $\begin{array}{l}\text { Conceptualization, Methodology, Validation, Software, Investigation, Formal Analysis, } \\
\text { Writing Original Draft Preparation, Writing Review and Editing and Supervision. }\end{array}$ \\
\hline SK & (iD) $0000-0002-7360-269 \mathrm{X}$ & Methodology, Writing - Original Draft Preparation and Writing - Review and Editing. \\
\hline MS & (iD) $0000-0002-8220-3885$ & Methodology, Writing - Original Draft Preparation and Writing - Review and Editing. \\
\hline $\mathrm{FG}$ & (iD) $0000-0003-3913-7963$ & Methodology, Writing - Original Draft Preparation and Writing - Review and Editing. \\
\hline SP & (iD) $0000-0001-7177-4407$ & Writing - Original Draft Preparation and Writing - Review and Editing. \\
\hline MD & (iD) $0000-0002-0622-4895$ & $\begin{array}{l}\text { Formal Analysis, Writing - Original Draft Preparation and Writing - Review and } \\
\text { Editing. }\end{array}$ \\
\hline
\end{tabular}

\section{Financial Support}

None.

\section{Conflict of Interest}

The authors declare no conflicts of interest.

\section{References}

[1] Li Y, Jacox LA, Little SH, Ko CC. Orthodontic tooth movement: The biology and clinical implications. Kaohsiung J Med Sci 2018; 34(4):207-14. https://doi.org/10.1016/j.kjms.2018.01.007

[2] Shipley T, Farouk K, El-Bialy T. Effect of high-frequency vibration on orthodontic tooth movement and bone density. J Orthod Sci 2019; 8(1):15. https://doi.org/10.4103/jos.jos_17_19

[3] Krishnan V, Davidovitch Z. Cellular, molecular, and tissue-level reactions to orthodontic force. Am J Orthod Dentofacial Orthop 2006; 129(4):469.e1-32. https://doi.org/10.1016/j.ajodo.2005.10.007

[4] Masella RS, Meister M. Current concepts in the biology of orthodontic tooth movement. Am J Orthod Dentofacial Orthop 2006; 129(4):458-68. https://doi.org/10.1016/j.ajodo.2005.12.013

[5] Meikle MC. The tissue, cellular, and molecular regulation of orthodontic tooth movement: 100 years after Carl Sandstedt. Eur J Orthod 2006; 28(3):22 1-40. https://doi.org/10.1093/ejo/cjloo 1

[6] Liu J, Li Q, Liu S, Gao J, Qin W, Song Y, et al. Periodontal ligament stem cells in the periodontitis microenvironment are sensitive to static mechanical strain. Stem Cells Int 2017; 2017:1380851. https://doi.org/10.1155/2017/1380851

[7] Cuoghi OA, Topolski F, de Faria LP, Ervolino E, Micheletti KR, Miranda-Zamalloa YM, et al. Correlation between pain and hyalinization during tooth movement induced by different types of force. Angle Orthod 2019; 89(5):788-96. https://doi.org/10.2319/041118-273.1

[8] von Böhl M, Kuijpers-Jagtman AM. Hyalinization during orthodontic tooth movement: a systematic review on tissue reactions. Eur J Orthod 2009; 31(1):30-6. https://doi.org/10.1093/ejo/cjno80 
[9] Luppanapornlarp S, Iida J. Orthodontic force, tooth movement, and interleukin-1 $\beta$. Hokkaido J Dent Sci 2017; 38(Special issue):20-7.

[10] Maltha JC, Kuijpers-Jagtman AM, Von den Hoff JW, Ongkosuwito EM. Relapse revisited — Animal studies and its translational application to the orthodontic office. Semin Orthod 2017; 23(4):390-8. https://doi.org/10.1053/j.sodo.2017.07.009

[11] Friedrichsdorf SP, Arana-Chavez VE, Bradaschia-Correa V, Cattaneo PM, Dominguez GC. Infrared light-emitting diode (LED) effects on orthodontic tooth movement. Braz Dent J 2019; 30(4):410-16. https://doi.org/10.1590/0103-6440201902416

[12] Peron APLM, Johann ACBR, Papalexiou V, Tanaka OM, Guariza-Filho O, Ignácio SA, et al. Tissue responses resulting from tooth movement surgically assisted by corticotomy and corticision in rats. Angle Orthod 2017; 87(1):118-24. https://doi.org/10.2319/102915-731.1

[13] Krishnan V, Viecilli RF, Davidovitch ZE. Cellular and Molecular Biology Behind Orthodontic Tooth Movement. In: Krishnan V, Davidovitch Z. Biological Mechanisms of Tooth Movement. 2nd. ed. London: John Wiley \& Sons, Ltd.; 2015. https://doi.org/10.1002/9781118916148.ch3

[14] von Böhl M, Maltha JC, Von Den Hoff JW, Kuijpers-Jagtman AM. Focal hyalinization during experimental tooth movement in beagle dogs. Am J Orthod Dentofacial Orthop 2004; 125(5):615-23. https://doi.org/10.1016/j.ajodo.2003.08.023

[15] Will LA. Orthodontic tooth movement: a historic prospective. Front Oral Biol 2016; (18):46-55. https://doi.org/10.1159/000351899

[16] Lobprise HB. Occlusion and Orthodontics. In: Lobprise HB, Dodd JR. Wiggs Veterinary Dentistry. 2nd ed. London: Wiley Blackwell; 2019. pp. 411-437.

[17] Janjic M, Docheva D, Trickovic Janjic O, Wichelhaus A, Baumert U. In vitro weight-loaded cell models for understanding mechanodependent molecular pathways involved in orthodontic tooth movement: a systematic review. Stem cells Int 2018; 2018:3208285. https://doi.org/10.1155/2018/3208285

[18] An S, Huang X, Gao Y, Ling J, Huang Y, Xiao Y. FGF-2 induces the proliferation of human periodontal ligament cells and modulates their osteoblastic phenotype by affecting Runx2 expression in the presence and absence of osteogenic inducers. Int J Mol Med 2015; 36(3):705-11. https://doi.org/10.3892/ijmm.2015.2271

[19] Seo BM, Miura M, Gronthos S, Bartold PM, Batouli S, Brahim J, et al. Investigation of multipotent postnatal stem cells from human periodontal ligament. Lancet 2004; 364(9429):149-55.

https://doi.org/10.1016/So 140-6736(04)16627-0

[20] Zeng X, Zhang Y, Kwong JSW, Zhang C, Li S, Sun F, et al. The methodological quality assessment tools for preclinical and clinical studies, systematic review and meta-analysis, and clinical practice guideline: a systematic review. J Evid Based Med 2015; 8(1):2-10. https://doi.org/10.1111/jebm.12141

[21] Kraiwattanapong K, Samruajbenjakun B. Effects of different force magnitudes on corticotomy-assisted orthodontic tooth movement in rats. Angle Orthod 2018; 88(5):632-37. https://doi.org/10.2319/103117-736.1

[22] Tomizuka R, Shimizu Y, Kanetaka H, Suzuki A, Urayama S, Kikuchi M, et al. Histological evaluation of the effects of initially light and gradually increasing force on orthodontic tooth movement. Angle Orthod 2007; 77(3):410-6.

[23] Iino S, Sakoda S, Ito G, Nishimori T, Ikeda T, Miyawaki S. Acceleration of orthodontic tooth movement by alveolar corticotomy in the dog. Am J Orthod Dentofacial Orthop 2007; 131(4):448.e1-8. https://doi.org/10.1016/j.ajodo.2006.08.014

[24] Kohno T, Matsumoto Y, Kanno Z, Warita H, Soma K. Experimental tooth movement under light orthodontic forces: rates of tooth movement and changes of the periodontium. J Orthod 2002; 29(2):129-35. https://doi.org/10.1093/ortho/29.2.129

[25] Liao W, Okada M, Inami K, Hashimoto Y, Matsumoto N. Cell survival and gene expression under compressive stress in a three-dimensional in vitro human periodontal ligament-like tissue model. Cytotechnology 2016; 68(2):249-60. https://doi.org/10.1007/s10616-014-9775-3

[26] Benjakul S, Jitpukdeebodintra S, Leethanakul C. Effects of low magnitude high frequency mechanical vibration combined with compressive force on human periodontal ligament cells in vitro. Eur J Orthod 2018; 40(4):356-63. https://doi.org/10.1093/ejo/cjx062

[27] Yi J, Yan B, Li M, Wang Y, Zheng W, Li Y, et al. Caffeine may enhance orthodontic tooth movement through increasing osteoclastogenesis induced by periodontal ligament cells under compression. Arch Oral Biol 2016; 64:5160. https://doi.org/10.1016/j.archoralbio.2015.12.009

[28] Li ML, Yi J, Yang Y, Zhang X, Zheng W, Li Y, et al. Compression and hypoxia play independent roles while having combinative effects in the osteoclastogenesis induced by periodontal ligament cells. Angle Orthod 2016; 86(1):66-73. https://doi.org/10.2319/121414.1

[29] Jin Y, Li J, Wang Y, Ye R, Feng X, Jing Z, et al. Functional role of mechanosensitive ion channel Piezo1 in human periodontal ligament cells. Angle Orthod 2015; 85(1):87-94. https://doi.org/10.2319/123113-955.1

[30] Kirschneck C, Proff P, Maurer M, Reicheneder C, Römer P. Orthodontic forces add to nicotine-induced loss of periodontal bone. J Orofac Orthop 2015; 76(3):195-212. https://doi.org/10.1007/s00056-015-0283-7 
[31] Jianru YI, MeiLe LI, Yang Y, Zheng W, Yu LI, Zhao Z. Static compression regulates OPG expression in periodontal ligament cells via the CAMK II pathway. J Appl Oral Sci 2015; 23(6):549-54. https://doi.org/10.1590/1678-775720150156

[32] Proff P, Reicheneder C, Faltermeier A, Kubein-Meesenburg D, Römer P. Effects of mechanical and bacterial stressors on cytokine and growth-factor expression in periodontal ligament cells. J Orofac Orthop 2014; 75(3):191-202. https://doi.org/10.1007/s00056-014-0212-1

[33] Kim SJ, Park KH, Park YG, Lee SW, Kang YG. Compressive stress induced the up-regulation of M-CSF, RANKL, TNF- $\alpha$ expression and the down-regulation of OPG expression in PDL cells via the integrin-FAK pathway. Arch Oral Biol 2013; 58(6):707-16. https://doi.org/10.1016/j.archoralbio.2012.11.003

[34] Mitsuhashi M, Yamaguchi M, Kojima T, Nakajima R, Kasai K. Effects of HSP7O on the compression force-induced TNF- $\alpha$ and RANKL expression in human periodontal ligament cells. Inflamma Res 2011; 60(2):187-94. https://doi.org/10.1007/s00011-010-0253-x

[35] Römer P, Köstler J, Koretsi V, Proff P. Endotoxins potentiate COX-2 and RANKL expression in compressed PDL cells. Clin Oral Investig 2013; 17(9):2041-8. https://doi.org/10.1007/s00784-013-0928-0

[36] Allgayer S, Menezes LM, Rinaldi MRL. Cytokines in crevicular fluid and orthodontic force: a systematic review. Rev Odonto Ciênc 2017; 32(2):104-10. https://doi.org/10.15448/1980-6523.2017.2.26330

[37] Giannopoulou C, Dudic A, Pandis N, Kiliaridis S. Slow and fast orthodontic tooth movement: an experimental study on humans. Eur J Orthod 2016; 38(4):404-8. https://doi.org/10.1093/ejo/cjv070

[38] Ren Y, Maltha JC, Kuijpers-Jagtman AM. Optimum force magnitude for orthodontic tooth movement: a systematic literature review. Angle Orthod 2003; 73(1):86-92.

[39] Reitan K, Kvam E. Comparative behavior of human and animal tissue during experimental tooth movement. Angle Orthod $971 ; 41(1): 1-14$.

[40] Ioi H, Kido MA, Murata N, Nishioka M, Asakawa M, Muroya R, et al. Effect of allergy on root resorption induced by orthodontic tooth movement. In: Bourzgui F. Issues in Contemporary Orthodontics. London: IntechOpen Limited; 2015. https://doi.org/10.5772/59972

[41] Kvam E. Scanning electron microscopy of tissue changes on the pressure surface of human premolars following tooth movement. Scand J Dent Res 1972; 80(5):357-68.

[42] Kang YG, Nam JH, Kim KH, Lee KS. FAK pathway regulates PGE2 production in compressed periodontal ligament cells. J Dent Res 2010; 89(12):1444-9. https://doi.org/10.1177/0022034510378521 